\title{
The Language of Ethics and Double Standards in the Affective and Sexual Socialization of Youth. Communicative Acts in the Family Environment as Protective or Risk Factors of Intimate Partner Violence
}

\author{
Oriol Rios-González ${ }^{1 *}$, Juan C. Peña Axt ${ }^{2}$, Elena Duque Sánchez ${ }^{3,4}$ and \\ Lena De Botton Fernández ${ }^{4}$ \\ ${ }^{1}$ Pedagogy, Universidad Rovira i Virgili, Tarragona, Spain, ${ }^{2}$ Instituto de Estudios Sociales y Humanísticos IDESH, Universidad \\ Autónoma de Chile, Santiago, Chile, ${ }^{3}$ Theory and History of Education, University of Barcelona, Barcelona, Spain, \\ ${ }^{4}$ Sociology, University of Barcelona, Barcelona, Spain
}

OPEN ACCESS

Edited by:

Luca Rollè,

Università degli Studi di Torino, Italy

Reviewed by:

Vincenzo Bochicchio,

University of Calabria, Italy

Chloe Rogers,

University of Hertfordshire,

United Kingdom

*Correspondence:

Oriol Rios-González

joseoriol.rios@urv.cat

Specialty section:

This article was submitted to Gender, Sex and Sexuality Studies,

a section of the journa

Frontiers in Sociology

Received: 17 April 2018

Accepted: 15 June 2018

Published: 04 July 2018

Citation:

Rios-González O, Peña Axt JC,

Duque Sánchez $E$ and

De Botton Fernández L (2018) The

Language of Ethics and Double Standards in the Affective and Sexual Socialization of Youth. Communicative

Acts in the Family Environment as Protective or Risk Factors of Intimate Partner Violence. Front. Sociol. 3:19.

doi: 10.3389/fsoc.2018.00019
One of the explanatory factors for the perpetuation of intimate partner violence (IPV) is the socialization process. There is broad literature on the role of family in socializing gender roles and the influence on reproducing IPV. However, less research has been developed on the effects of communicative acts in the family environment as a protective or risk factor in front of IPV. This article presents sound evidence confirming the presence of language of ethics that is reproducing stereotyped models of attraction in heterosexual relationships, which empties good people of attractiveness and indirectly contributes to maintain the link between desire and aggressiveness. The language of ethics is characterized by integrating speech acts that exclusively include ethics and exclude desire when talking about egalitarian boys or men. To analyze this reality, a qualitative study has been conducted framed in the communicative methodology. This methodology has been recommended by the European Commission to conduct research on vulnerable groups and social inequalities, which has the aim to advance knowledge on social transformation. Drawing on this approach, three different data-collection techniques have been implemented: in-depth interviews, daily-life stories and focus groups. The fieldwork includes a sample of 52 young men and women between the ages of 18 and 23 from a vocational training high school, and 4 fathers and 4 mothers of some of these young people. The findings confirm the existence of a model of socialization that replicates family relations based on the maintenance of the double standards. Thus, mothers used to employ the language of ethics with their daughters fostering a controversial effect, that is, the latter prefer to start affective and sexual relationships with boys who are aggressive and not egalitarian. On the other hand, fathers used to employ language of desire with their sons stimulating the performance of chauvinist behaviors that denigrate women and girls.

Keywords: language of ethics, language of desire, communicative acts, family relations, socialization, intimate partner violence 


\section{INTRODUCTION}

Research on family and gender issues has analyzed intimate partner violence (IPV) reaching different conclusions (Teaster et al., 2006; Valls et al., 2008, 2016; Yount and Li, 2009; Martin et al., 2013; Medrano et al., 2017; Vidu et al., 2017). One of these conclusions concerns on the central role that socialization process has in the reproduction of this problem. The research presented in this article coincides in some points with these analyses but get new explanations on how communication established within the family context helps to perpetuate counter-productive socialization processes that could lead toward violent relationships. Thus, the main hypothesis that we start from is: Communicative acts settled in daily family interactions, including verbal and non-verbal language, are fostering the maintenance of a double-standard discourse in relation to young people's affective and sexual relationships. Hence, despite the broad knowledge about affective and sexual relationships in young generations, little research has examined how socialization on double-standards discourses is articulated in the interactions and communicative acts established between parents and teenagers. In the present study we will pay attention to the definition! that Berger and Luckmann (1991) established about socialization where primary and secondary processes are differentiated. Following these authors, primary socialization implies to externalize the individual's being into the social world and internalize it as an objective reality. On the other hand, secondary socialization implies also an internalization of institutional or institution-based "sub-worlds," such as the division of labor (Berger and Luckmann, 1991, p. 158). Additionally, we also consider the conceptualization of communicative acts understood as verbal and nonverbal language that daily influence people's actions, decisions and desires (Habermas, 1985). This article will deepen on family interactions aimed at showing how heterosexual girls and boys start conversations with their parents that have an impact on their preferences and decisions concerning sexual-affective relationships which are closely linked with IPV. This analysis provides new insights that help to comprehend the reasons for the persistence of this phenomena among youth. This article is comprised by four sections. The first part presents a literature review regarding previous research on family socialization and language, socialization of emotions, socialization of attractiveness and socialization of gender stereotypes and masculinity. The second part introduces the methodological paradigm and datacollection instruments used. In the third section, the findings are detailed, and finally, in the fourth section the main conclusions of the research are summarized.

The research on family socialization makes several contributions in referring to models of attractiveness and sexual-affective relationships, in this article we present four key themes on this line that have been identified throughout a wide literature review. Firstly, there are a set of studies that go deep into the interactions and social meanings that are expressed through language and how these constitute the main form of socialization in the family environment. Secondly, there are analyses based on the emotions defined within the family environment which are constructed through language. Thirdly, there is research that stresses how socialization framed on the family environment promotes specific models of attractiveness. Lastly, there are contributions that provide evidence on the effects of language use on the definition of gender stereotypes and masculinity models.

Regarding the block of studies which pays attention on interactions, social meanings and language, it is important to mention again the analysis conducted by Berger and Luckmann (1991). They underscore the relevance of family environment in the socialization process starting from the premise that is during childhood, and through interactions with family members, that a person learns how to become part of society. This process happens through children's identification with others that makes them accept certain roles and attitudes. Other key social theorists such as Parsons and Bales (1955) put family as the first socializing institution in industrial societies. They highlighted that nuclear family, and particularly mothers, was the social system that guarantees the proper internalization of social life. Along these lines, Schutz (1967) stated that the lifeworld is the world in which the experience of others constitutes a fundamental element in the formation of self-perceptions. Therefore, the lifeworld is inter-subjective and culturally shared through symbols such as language. Socialization, then, is mainly a social learning which implies the acquisition of structures, behaviors and tastes; and language has a lead role in consolidating that process.

Later, Habermas (1985) goes beyond and argued that the process of rationalization of the lifeworld creates more egalitarian patterns of relationships which are changing the socialization process inside the family environment. In fact, this change on the vision of the role that nuclear family has in modern societies began when this family model started to be considered as the basis of a decadent society (Beck-Gernsheim, 2002). Hence, from mid of 1950's to nowadays, family's functions and forms have been modified, however, and despite of these changes, research shows that family continues having a fundamental role in children's socialization (Mitchell, 2010; Rollins and Hunter, 2013; Höppner, 2017).

Regarding the group of analyses which deepen on the socialization of emotions, research indicates that the formation of emotions in individuals is established mainly within the family (Garner et al., 1997; Elster, 2007; Hunter et al., 2011; Mandara et al., 2012; Shaffer et al., 2012). For instance, Elster (2007) affirms that emotions are based on beliefs and these are defined in socialization processes, so they are transmitted. He indicates that family contributes to inform children about the meaning of these emotions and this helps the latter to properly understand their feelings. Other authors, such as Hunter et al. (2011) and Shaffer et al. (2012) go further into explaining how these emotions are socialized in the family environment. Shaffer et al. (2012) shows that there is a direct influence between emotional development and the kind of family to which the individuals belong. Families shape emotions according to certain risk factors in relation to housing and socio-economic status and these issues directly affect children's feelings (Shaffer et al., 2012). In the same vein, Hunter et al. (2011) focus on how children's emotions are directly related to their parents' emotions, finding evidence that 
parents' strategies influence young people's emotional beliefs. This research also maintains that there are socializing differences between fathers and mothers; therefore, how young men and women develop their personality depends directly on how parents interact with their children. Consequently, children whose mothers participate more in emotional socialization have more capacity for emotional regulation than those whose mothers are less present in that process. Finally, on this group of studies focused on emotions and similarly than the above mentioned analyses, there are researches which conclude that this emotional socialization within family environment leads to reproduce gender stereotypes, for example the promotion of gender identities based on the distinction between a tougher boy or a fragile girl (Garner et al., 1997; Botello, 2017). Mandara et al. (2012), who performed a research with African-American mothers, also illustrate that stereotyping process, finding that those mothers who take care of daughters are more relaxed and less negative than those who take care of sons. Drawing on a psychological perspective, Brown (2011) deepens on this regard exploring how prejudice is constructed during childhood. He concluded that social behaviors are shaped on these tendencies established throughout individual personality, but insisting on the fact that attitudes and actions are also influenced by the social groups that each person belongs.

The third section of this literature review is focused on the socialization of attractiveness and how language is a key element on this regard. There is an important amount of analyses that stress the fact that models of attractiveness are socially constructed and this becomes a procedure which is influencing people's choices on relation to sexual and affective relationships (Valls et al., 2008; Díez-Palomar et al., 2014; Gomez, 2015; Puigvert, 2016). This group of researches starts from a conceptualization of models of attractiveness that understand them as social patterns which provide of desire or valorization particular types of masculinities and feminities (Padrós, 2012). Therefore, every-day interaction spaces, like the ones established in family, contribute to foster or reject certain models of attractiveness, so these spaces become very important at early ages. Recent studies on this line illustrate an alarming problem concerning the existence of models of attractiveness which are connected to violent behaviors, this means that young people and adolescents are being socialized on attraction toward violence and this can drive them to toxic relationships marked by IPV (Valls et al., 2008). Valls et al. (2008) confirmed that issue and they discovered that this link between aggressiveness and attractiveness is due a chauvinist socialization process which promotes desire toward masculine models that are dominant and violent.

The influence of language in the abovementioned process is strongly important in people, but particularly in teenagers, because it can associate beauty with ethical or non-ethical elements (Ríos and Christou, 2010). Thus, research differentiates between language of ethics and language of desire in order to explain the types of languages that people employ to promote one thing or another. Accordingly, it is quite common to use the language of desire to foster desire and admiration for dominant traditional males, and the language of ethics to talk about egalitarian males (Castro and Mara, 2014; Schubert and Valls-Carol, 2015). As a consequence of this common practice the reproduction of a double-standards scheme is perpetuated (DíezPalomar et al., 2014). Double standards are understood in that case as the persistence of a desire toward men who have power but not ethical values, and, on the other hand, the maintenance of a feeling of friendship toward men that have egalitarian and solidary attitudes but without power positions (Gomez, 2015). McCarthy and Casey (2008) coincide with this analysis and they indicate an attraction toward violence in young cohorts. These authors also pay attention on the role that family has on this link and they argued that some young people feel their relationship with their parents is weakening, so they seek to fill this emotional void with partners associated with violence. Thus, one of the most relevant conclusions of this research is that many young people separate passionate attraction and non-passionate love, linking the former with violence and the latter with stability.

Finally, the last part of this literature review refers to gender socialization and the construction of masculinity. The analyses on this field are centered mainly on the study of how hegemonic gender models are socialized and reproduced (Kimmel, 2000; Connell, 2005; Javaid, 2017). Concerning the study of masculine gender models, research has especially highlighted the perpetuation of a traditional and hegemonic masculinity model through cultural dominance and violence (Connell, 2005; Shumka et al., 2017). From that position, the definition of two central gender models has been conceptualized from the studies of Connell et al. (1985): emphasized femininity and hegemonic masculinity. Both arise from the definition of hegemony provided by Gramsci and refer to cultural practices that have been maintained as central in gender socialization. Hence, hegemonic masculinity is understood as this model of masculinity that becomes predominant excluding other models to be successful or more visible.

Research that pays attention to this matter also highlights the role that communicative acts performed in the family setting has in the shaping of hegemonic masculinity as a successful model. For instance, Schrock and Schwalbe (2009) show that men who principally define themselves as egalitarian because share domestic chores sometimes carry out a series of communicative acts that reinforce hegemonic masculinity. In this way, through acts such as showing disdain for the tasks carried out by their female partners, men who are apparently egalitarian perform communicative acts of dominance, thereby reproducing gender inequalities. Along the same lines, Hughey (2011) notes that in the United States of America, chauvinist and racist speech continues to be reproduced by some white men in the intimacy of their homes. This author maintains that there are many white men who publicly show tolerance with pro-feminist and anti-racist speech but that in the intimacy of their homes they reproduce speech acts that encourages gender and race inequality. These two studies show that the family environment, in some cases, reproduces gender stereotypes where the traditional model of masculinity is promoted. Then, research framed on men's studies clarify the distinction between traditional and egalitarian masculinities that help to comprehend the reproduction of these gender disparities (Flecha et al., 
2013; Castro and Mara, 2014). This distinction is based on the conceptualization of three ideal-types: Dominant Traditional Masculinity (DTM), Oppressed Traditional Masculinity (OTM), and New Alternative Masculinities (NAM). DTM perpetuates chauvinism and IPV, OTM is not violent but can act reproducing chauvinism and double-standards, and contrarily NAM goes beyond and these are the egalitarian men who are neither violent nor chauvinist, overcoming double standards practices. The review on masculinities carried out by Bridges and Pascoe (2014) also pays attention on the emergence of a "hybrid masculinity" which distances from traditional models of masculinity. This typology of masculinity combines toughness and tenderness and, in spite of this alternative gender performance, is not understood as a profound challenge to hegemonic masculinity. Contrarily, these hybrid masculinities are perceived as a contemporary interpretation of the existing gender and sexual inequalities. In a similar vein, Connell (2012), in her reformulation of hegemonic masculinity in the globalization era, realizes an important distinction between violent and non-violent hegemonic masculinities. She affirms that there are men who perform chauvinist behaviors and practices but not being violent, on the other hand she also maintains there are men who portray this hegemonic masculinity being violent and chauvinistic at the same time. All of these studies on the influence of socialization on people's subjectivity and on the role of language in that process, particularly in the shaping of attractiveness or gender stereotypes, highlight the relevant role of family for understanding the mechanisms that reconfigure people's identity and behaviors. Nevertheless, there is a gap in the research that examines how the language employed in the family environment, especially by parents, influences young people's attraction patterns and the reproduction of the double standards. This article will provide data on all these aspects.

\section{MATERIALS AND METHODS}

\section{Methodological Paradigm}

To gather the evidence on the influence of language employed in the family environment in the socialization process of youth, a qualitative methodology, that took the communicative perspective into account, was employed (Gómez et al., 2011). The main characteristic of research that adopts a communicative perspective is that subjects participate in the research with a horizontal relationship with the researchers. This egalitarian approach is established at the beginning of the research process, where subjects discuss key aspects such as the design of the datacollection instruments and the conclusions reached through the field work analysis (Flecha and Gómez, 2004). In the present study, an advisory board formed by young people, parents, and people involved in the struggle against gender violence was created to satisfy this communicative premise.

\section{Study Design and Sample Description}

The research was based on a case study carried out in a vocational training school in Barcelona (Spain), which was selected because of its social and cultural diversity that is quite representative of the socio-demographic reality of the city. Thus, in this school there are students and families which come from Latin-America and North-African countries as well as from Spain. They also come from different socio-economic backgrounds, but the school is mainly attended by students of middle class, low-middle class, and working class. The sample $(n=60)$ includes young people, heterosexual men and women ranging from 18 to 23 years old that are attending vocational training, particularly who are registered in courses of personal image, aesthetics and beauty, and telecommunications. The sample is completed with eight mothers and fathers of the young interviewees. In this regard, the group of young people who were involved in the field work were selected discussing with the principal of the school its appropriateness, in particular with the objective to guarantee the criteria of socio-cultural diversity mentioned above. Furthermore, only those parents who accepted to be interviewed were included in the sample.

Three different data collection instruments were employed: life stories, in-depth interviews, and focus groups. Life-stories were conducted with the objective of deepening on specific moments of students' life. In fact, the nature of this instrument helped creating an atmosphere where young people openly and sincerely explained dialogues and interactions with their parents. The objective of this instrument is not to carry out a biography but to construct a reflexive narration about subjects' daily life in order to deepen on their present, past and future expectations. This is an instrument that allows researchers to identify how barriers faced in subjects' life are overcome. To complement this data, the research team decided to perform focus groups with young people who were already friends and had enough confidence to expound their family relations in public. Lastly, in-depth interviews addressed to mothers and fathers were developed in order to consider parents' perspective that could be contrasted with young people's visions. More detailed information on these data-collection techniques is presented in Table 1.

\section{Data Analysis}

The analysis of the information was carried out aimed at obtaining knowledge which would be useful to understand the

TABLE 1 | Summary of data collection instruments and profiles.

\begin{tabular}{lcccl}
\hline Technique & $\begin{array}{c}\text { No. of } \\
\text { techniques }\end{array}$ & \multicolumn{2}{l}{$\begin{array}{l}\text { Gender of } \\
\text { participants }\end{array}$} & Profile \\
\cline { 2 - 4 } & 20 & 10 & 10 & Young people \\
\hline Life stories & $4^{\mathrm{a}}$ & 4 & 4 & Family members \\
$\begin{array}{l}\text { In-depth } \\
\text { Interviews }\end{array}$ & $6^{\mathrm{b}}$ & 16 & 16 & Young people \\
Focus groups & 30 & 30 & 30 & Total: 60 \\
\hline Total & & & &
\end{tabular}

a The interviews were applied to father and mother simultaneously. This allowed us to have much more relevant information regarding the interactions that happen within the intimacy of the family.

${ }^{b}$ Communicational discussion groups applied are: two coed groups of communicational discussion, to communicational discussion groups of women and two communicational discussion groups of men. 
reproduction of the double-standards discourse. Thus, the data analysis was focused on identifying communicative acts which maintain this discourse paying particular attention on how the language of desire and the language of ethics are used by young and adult people (parents). Drawing on these premises, all the data collection instruments employed were verbatim transcribed and the quotes emerging were selected to respond the research hypothesis: Communicative acts settled in daily family interactions, including verbal and non-verbal language, are fostering the maintenance of a double-standard discourse in relation to young people's affective and sexual relationships.

Later, we categorized the information considering three main criteria: (a) how communicative acts are used to reproduce the double standards discourse (which kind of language is employed-ethics or desire); (b) who perform the communicative acts (parents or young people); and (c) which implications these communicative acts have in young people's decisions and interests regarding their sexual and affective relationships. The findings obtained were widely discussed with the advisory board that validate their appropriateness.

\section{RESULTS}

Drawing on the previously presented analytical scope, four key issues emerge from our analysis which illustrate these elements that perpetuate the double standards discourse in family relations. First, the reproduction of the language of ethics to speak about boys in the family environment is discussed. Second, evidence on mothers as the main actors who employ the language of ethics is presented. Third, insights are provided about fathers involved in discussions where the double standards about boys' sexual and affective relationships are reproduced. Lastly, the consequences that the use of the language of ethics in the family environment have on young people are explained.

\section{Language of Ethics in the Family Environment}

Among the families who participated in the research, the way that attractiveness toward alternative models of masculinity is promoted is highly important and mainly occurs through the use of the language of ethics. The language of ethics is used focusing on men who are considered morally appropriate to maintain sexual-affective relationships. All participants are able to clearly define what characteristics men should have to become a successful boyfriend from relatives' point of view, particularly incorporating aspects that are "ethically" highly valued. However, it can be observed that desire is not discussed when people talk about these boys, as shown in the following quote, where a mother expresses her desire that her daughter relates with a "formal" kind of man. The verbal language she uses clearly differentiates between two kinds of men, one forged in egalitarian values and another branded by completely contrary values.

Mother: "I always worry that she doesn't just go out with anyone, that the guys that she is with should be nice. That's why I always tell her that she has to look for guys that are worth it, not bums." (In-depth interviews, family members)
The research also shows that the interactions in this kind of language have a contrary effect and it is precisely socializing heterosexual women to develop an attraction toward men who may cause them trouble. The following sentence confirms this kind of interaction that is mainly generated between the two generations. Here the language that is linked to kindness, but lack of desire, is used to describe these "good guys" but generates an evident rejection.

Mother: I remember when Esteban used to come here. He came every day to walk her to school, but she never paid attention to him.

Father: But he has always been in love with her, since they were little.

Mother: But I tell you, never, and the guy didn't lack for trying. I told her that he's a good guy, that he looked nice and things like that. But she didn't like him. At the end, the guy just got bored and found himself a girlfriend. But I think that if she tells him to come back, he'll come running.

\section{I: And when you spoke to her about him, what did she tell you?}

Mother: That I was right, that he was very good, but she didn't like him. (In-depth interviews, family members)

This dialogue between the researcher and the interviewee shows how the mother sees in the boy a good and proper man for her daughter, that is, ethically well valued. However, the daughter does not find him attractive. At the same time, this quote exemplifies the fact that the mother is the person in the family who predominantly talks about these issues with her children. The following lines reveal more details about this issue.

Mothers and the Language of Ethics

The thing is that my dad doesn't care about these issues. The one who does is my mother.

\section{I: And what did she tell you?}

That I should be careful, I should be careful with boys who are too aggressive because they can drive you on the wrong track. (Caro, 19 years, life stories)

As shown in the above quote, girls sometimes choose to talk about their intimate life with their mothers. In this sense, the field work shows that girls feel much more open to discuss the topic of love and relationships with relatives of their same gender, in this case with their mothers. The following quote is extracted from an interview with a father and a mother, where the aforementioned tendency is confirmed.

Father: I don't talk about those things with her.

Mother: I am the one who speaks about boyfriends with her; she's always telling me stuff. Every day I ask her about it. Not him; he tells her that he doesn't want to talk about those topics with her. (In-depth interviews, family member) 
These interactions happen when comfortable communication facilitates intimate discussion, for example, when mothers try to approach and get to know their daughters better. Likewise, one of the interviewed mothers explains how she maintains certain dialogue and communication strategies with her daughter to keep her away from men who she, as a mother, does not consider adequate for her daughter. These spaces of communication and intimacy allow interactions that link formality and equality through the language of ethics. In the following quote, this type of interaction is confirmed when a mother refers to the man she considers adequate for her daughter. She does not use a language of desire to describe him; on the contrary, she talks about him employing words linked to kindness.

Mother: I am always telling her if somebody is no good for her. I tell her that she has to think about the future, that she should think if that guy she likes has a future. In the beginning, she always gets angry, but when she meets another guy, she tells me. (In-depth interviews, family members)

The previous quotes also illustrate how the mother makes direct use of the language of ethics to socialize her daughter toward a model of man, ruling out the man who she does not consider satisfactory for her daughter. Talking in this way has the objective of influencing her daughter's choice but utilizing adjectives that are fundamentally based on ethical issues. For instance, as shown in the next quotation, adjectives full of ethical connotations are used. The first one refers to boys as "studious" and the second one as "normal," but none of them have elements that connect with young people's conceptions of attractiveness and desire.

\begin{abstract}
"My mother talks to me more like a friend. My mother is always telling me that I should look at normal boys that are not too lazy, so if tomorrow I can be with them, then it should be all right. That they don't treat me bad or that I have to support them and things like that. That they study, normal, not dumb, but normal". (Cris, 18 years, life stories)
\end{abstract}

In contrast, the language used by fathers to address attraction and relationships is radically different. Mothers' words are more connected with ethics, while fathers use language, mostly when speaking with boys that is not ethically constructed. This topic will be analyzed more in depth in the next section, where different elements that reproduce the double standards will be described.

\section{Fathers and Double Standards}

In this study, fathers' involvement in socialization is different from that of mothers. Fathers foster double standards when interacting with their children, but only with boys. In this sense, the fathers who participated in this research have different attitudes depending on the gender of their children. The evidence gathered shows the differences in communication between fathers and their boys and girls in similar circumstances. Their language generates a reproduction of dominant traditional masculinity, mainly through the use of words that compare girls with objects, as shown in the following quote.
"My father tells my twin brother that he has to screw all the girls he can. But he doesn't tell me anything, and I can't tell him anything because I am his little girl" (Cris, 18 years, life stories)

This kind of language is disrespectful toward women; it separates itself from ethics and incorporates a sexual component. This component does not exist in the language used by mothers, who, as we have previously witnessed, are those who are most involved in discussions of attraction based on ethical issues. However, in the fathers' communicative acts, there are no transformative elements; on the contrary, they are reproducing elements that foster socialization based on double standards. In the following quote, we can observe this reality from the perspective of a young interviewee:

Yes, my father is a bit old-fashioned; he tells me to do the things that he used to do. Chauvinist-based things. For example, he tells me that I should just screw girls. (Xavi, 18 years, life stories)

Ultimately, as we have shown in previous quotes, fathers' and often mothers' language use contribute to the perpetuation of double standards. This does not help encourage alternative affective and sexual relationships in the next generations; on the contrary, a conservative conception is reinforced. The next quote exemplifies this reality: "My father always says... As long as she is hot, that's enough" (Adam, 20 years, life stories). In addition, this kind of language is also socializing boys into chauvinist values as it stated in the next quote where a homophobic statement is expressed. In that case, as Adam said, a father does not accept his son's homosexuality because will not be able to respond to his ideal of boy succeeding with girls: "His father is the one who says 'fuck', the only son that I have and that he is fagot" (Adam, 20 years, life stories).Therefore, consequences of this kind of language use with young generations must be widely explored, and in the next section, the thorough analysis carried out in this study will shed light on this issue.

\section{Consequences}

Two main consequences have been identified through the analysis of language use: (a) the reproduction of double standards-but paying attention in this case to the attractiveness of masculine dominant models - and (b) the lack of attractiveness of young males who have values but are considered only as friends and not as prospective partners in a sexual and affective relationship. Regarding double standards, several of the interviewed young women maintained that there are two kinds of men, some to have fun with and others to be boyfriends. These notions are reflected through the contradictions manifested by the interviewed girls at the time of choosing a partner. Influenced by the interactions they have had within their family environment, they end up making radically different choices regarding boys. This situation is reflected in the following quote, where the interviewee defines which characteristics a guy should have to capture her interest: "To go out with those that are bastards, that they make you laugh and such. And for a boyfriend, one that understands you, that is sincere". (Cris, 18 years, life stories). 
Thus, despite the attempts of families to socialize their daughters into relationships based on egalitarian values, the language of ethics that parents employ is not able to change or socialize their attractiveness toward alternative male models. In fact, they have the opposite effect by encouraging the attractiveness toward violence and even justifying it.

\begin{abstract}
Man, we like him to be like that, aggressive, because you know that whatever happens, he can defend you or they are going to respect you as well because you are his girlfriend. And nobody's going to say anything to you. (Paola, 19 years, life stories)
\end{abstract}

The second consequence is removing attractiveness from men of masculinity associated with egalitarian values. In this way, interactions within the family environment suggest the complete absence of attractiveness of egalitarian young men. The use of the language of ethics impacts the attractiveness of a model of men that their parents consider adequate for their daughters. This is known by women who see men whom their parents consider good for them directly as weak men or, as they call them, "mama's boys." This is reflected in the next quotation, where a young interviewee is asked about the attitude of her classmates in her high school, and she describes good men as weak: "You know what happens? When you are good, they tell them they are mama's boys." (Paola, 19 years, life stories). These "mama boys" do not generate any kind of desire, in fact their goodness is an explanatory element of this lack of desire, because goodness and attractiveness are separated: "there was a girl that said to me: I don't like him because he is too good and this doesn't turn me on, he isn't hot for me" (Lorena, 20 years, life stories).

These kinds of interactions, in which attractiveness is completely removed from young men with egalitarian values or well evaluated from an ethical point of view, is not an isolated incident. On the contrary, it is a situation in which the interactions between young people make evident the attractiveness toward violent masculine models. In the following quote, it is observed how a boy with values is questioned regarding his ability to be with a girl who, in the opinion of others, is much prettier.

I don't know, I have a friend who, let's see, is not good looking, sort of, and he has a good heart and... I don't know. And sure, he is with a really good looking girl and people tell her: How can you be with him? (Lorena, 20 years, life stories)

Consequently, it does not matter what values boys have; girls simply do not perceive these boys as attractive, and that is reason enough to question their relationships. As noted, emotions and attractiveness are socialized; therefore, these kind of interactions are not more than a product of socialization processes, in which families have an important role.

\section{DISCUSSION}

Drawing on the conclusions of the previous analyses collected in the literature review, there are several elements that contribute to understand the influence of socialization in the shaping of models of attractiveness and gender stereotypes. In addition, in those analyses the role that family environment and language have in these processes is evidenced. For instance, the literature helps reveal how conceptions of attractiveness are defined through daily interactions in different socializing spaces like family (Duque, 2006; Urpí and Naval, 2006; McCarthy and Casey, 2008; Gomez, 2015). Similarly, it also helps to comprehend how the construction of gender identity and people's emotions perpetuate affective and sexual relationships marked by the attraction toward violence (Kimmel, 2000; Connell, 2005; Schrock and Schwalbe, 2009; Hughey, 2011; Hunter et al., 2011; Shaffer et al., 2012). However, all these studies lack an explanation of the families' socializing role on young people's attraction patterns and the perpetuation of a double standard discourse.

In this research we try to respond this gap starting from the hypothesis: communicative acts settled in daily family interactions, including verbal and non-verbal language, are fostering the maintenance of a double-standard discourse in relation to young people's affective and sexual relationships. In this regard, we have collected evidences on how young people, particularly young girls, choose bad guys for their initial sexual or affective relationships and how these choices make them more vulnerable to suffer IPV. This last effect is an issue which has been widely explored by previous research (Bukowski et al., 2000) making visible how heterosexual girls who desire this typology of guys are more likely to have abusive dating or abusive marital relations. In fact, research has also demonstrated that the existence of a socialization process that links dominance and attractiveness is an important explanatory factor of IPV in teenagers (Valls et al., 2008). However, present investigation goes beyond these analyses and illustrates how girls' choices in their affective and sexual relationships are conditioned by the interactions and the language used within the family environment. These findings also illustrate that this language is centered on ethics and consequently in double standards. Thus, parents, especially mothers, used to perform a language of ethics with their daughters trying to promote egalitarian masculine models although they reach a controversial impact and finally young girls choose bad boys. On the other hand, research also shows how fathers, employing a language of desire with their sons, reproduce chauvinist and double standards discourses that imply maintaining traditional schemes on young people's sexual and affective interests.

Although previous research already identified the impact of communicative acts to favor attraction toward violence and the reproduction of double standards (Castro and Mara, 2014; Gomez, 2015), there are less analyses focused on how family relations could interfere on this process. Therefore findings presented here give new arguments about what interactions and what kind of language maintain these exclusionary dynamics in the family environment. Henceforth, to continue working on this line it is highly necessary to explore the mechanisms of constructing an alternative language in family relations, which would be based on desire and reject traditional and violent relationships as well as aggressive models of attractiveness. 
Beck (1992); Giddens (1994), and Beck-Gernsheim (2002) insist that reflexive modernity offers opportunities to reach this objective, to de-monopolize expert knowledge, to create deep revolutions in family intimacy and social movements. This modernity is characterized by a reformulation of subjects' personal relationships because more opportunities to establish an egalitarian dialogue, based on validity claims (Habermas, 1985), are settled. Hence, in current societies families and educational organizations are increasingly promoting interventions based on this constructive dialogue which are providing relevant knowledge to children and teenager for their choices in terms of sexual and affective relationships (Soler, 2017).

The results described in this article encompass many of these elements, meaning that their objective is to have a social impact on overcoming negative choices that young people take (Flecha et al., 2015; Reale et al., 2017). In short, considering all these elements, it can be stated that family relations and discussions can play a fundamental role in preventing IPV because they can position themselves as protagonists of a transformation in the socialization of attractiveness through linking the language of ethics with the language of desire.

\section{ETHICS STATEMENT}

The research conducted for the elaboration of this article followed the scientific and ethical procedures defined by the EU's Charter of Fundamental Rights and the UNESCO Universal

\section{REFERENCES}

Beck, U. (1992). Risk Society: Towards a New Modernity. London: Sage.

Beck-Gernsheim, E. (2002). Reinventing the Family: In Search of New Lifestyles. Weinheim: Wiley.

Berger, P. L., and Luckmann, T. (1991). The Social Construction of Reality: A Treatise in the Sociology of Knowledge. London: Penguin.

Botello, L. L. (2017). Análisis del "enojo" del varón en el contexto de la violencia contra las mujeres para trazar un marco de construcción de responsabilidad. Mascul. Soc. Change 6, 39-61. doi: 10.17583/MCS.2017.1923

Bridges, T., and Pascoe, C. J. (2014). Hybrid masculinities: new directions in the sociology of men and masculinities. Sociol. Compass 8, 246-258. doi: $10.1111 /$ soc4.12134

Brown, R. (2011). Prejudice: Its Social Psychology. Oxford: John Wiley \& Sons.

Bukowski, W. M., Sippola, L. K., and Newcomb, A. F. (2000). Variations in patterns of attraction of same-and other-sex peers during early adolescence. Dev. Psychol. 36:147. doi: 10.1037/0012-1649.36.2.147

Castro, M., and Mara, L. C. (2014). The social nature of attractiveness: how to shift attraction from the dominant traditional to alternative masculinities. Int. Multidiscip. J. Soc. Sci. 3, 182-206. doi: 10.4471/rimcis.2014.36

Connell, R. W. (2005). Masculinities. Cambridge: Polity Press.

Connell, R. W. (2012). Masculinity research and global change. Mascul. Soc. Change 1, 4-18.doi: 10.4471/mcs.2012.01

Connell, R. W., Kessler, S., Ashenden, D. J., and Dowsett, G. W. (1985). Gender relations in secondary schooling. Sociol. Educ. 58, 34-48. doi: 10.2307/2112539

Díez-Palomar, J., Capllonch, M., and Aiello, E. (2014). Analyzing male attractiveness models from a communicative approach socialization, attraction, and gender-based violence. Qual. Inq. 20, 844-849. doi: $10.1177 / 1077800414537205$

Duque, E. (2006). Aprendiendo Para el Amor o Para la Violencia. Las Relaciones en las Discotecas. Barcelona: El Roure Ciencia.
Declaration of Human Rights. The ethical standards of the investigation are taking into account the recommendations established in the field of Social Sciences and Humanities research of Horizon 2020. In this regard, informed consent forms were distributed among young and adult people involved in the study according the recommendations of the Ethical Regulations of the University of Barcelona where the study was conducted. These informed consent forms were properly responded and returned by students and parents of the students. Finally, it is also important to mention that research and its data collection instruments where validated by the Clinical Research Ethics Committee of the Bellvitge Hospital (Barcelona, Spain).

\section{AUTHOR CONTRIBUTIONS}

OR-G and LD contributed with the analysis of the field work and the elaboration of Results and Discussion sections. JP designed the investigation, conducted the data collection techniques and worked on the stated of the art section. ED participated in the elaboration and review of the state of the art of the article.

\section{ACKNOWLEDGMENTS}

This article is supported by the competitive research project: Uni4Freedom. Violències per raó d'orientació sexual, identitat o expressió de gènere a les universitats catalanes funded by the Programme Recercaixa (Caixa Bank).

Elster, J. (2007). Explaining Social Behavior: More Nuts and Bolts for the Social Sciences. Cambridge: Cambridge University Press.

Flecha, R., and Gómez, J. (2004). "Participatory Paradigms: Researching 'with' rather than 'on"' in Researching Widening Access: Issues and Approaches in an International Context, eds B. Crossan, J. Gallacher, and M. Osborne (London: Routledge), 129-140.

Flecha, R., Puigvert, L., and Rios, O. (2013). The new alternative masculinities and the overcoming of gender violence. Int. Multidiscip. J. Soc. Sci. 2, 88-113. doi: $10.4471 /$ rimcis.2013.14

Flecha, R., Soler-Gallart, M., and Sordé, T. (2015). Social impact: europe must fund social sciences. Nature 528:193. doi: 10.1038/528193d

Garner, P. W., Robertson, S., and Smith, G. (1997). Preschool children's emotional expressions with peers: the roles of gender and emotion socialization. Sex Roles 36, 675-691. doi: 10.1023/A:1025601104859

Giddens, A. (1994). "Living in a post-traditional society", in Reflexive Modernization: Politics, Tradition and Aesthetics in the Modern Social Order, eds U. Beck, A. Giddens, and S. Lash (Stanford, CA: Stanford University Press), 56-109.

Gómez, A., Puigvert, L., and Flecha, R. (2011). Critical Communicative Methodology: informing real social transformation through research. Qual. Inq. 17 , 235-245. doi: 10.1177/1077800410397802

Gomez, J. (2015). Radical Love. New York, NY: Peter Lang.

Habermas, J. (1985). The Theory of Communicative Action: Lifeworld and System: A Critique of Functionalist Reason. Boston, MA: Beacon Press.

Höppner, G. (2017). Rethinking socialization research through the lens of new materialism. Front. Sociol. 2:13. doi: 10.3389/fsoc.2017.00013

Hughey, M. (2011). Backstage discourse and the reproduction of white masculinities. Sociol. Q. 52, 132-153. doi: 10.1111/j.1533-8525.2010. 01196.x

Hunter, E. C., Katz, L. F., Shortt, J. W., Davis, B., Leve, C., Allen, N. B., et al. (2011). How do I feel about feelings? Emotion socialization in 
families of depressed and healthy adolescents. J. Youth Adolesc. 40, 428-441. doi: 10.1007/s10964-010-9545-2

Javaid, A. (2017). Masculinities, sexualities and identities: understanding HIV positive and HIV negative male rape victims. Int. Soc. 32, 323-342. doi: $10.1177 / 0268580917696387$

Kimmel, M. (2000). The Gendered Society. New York, NY: Oxford University Press.

Mandara, J., Murray, C. B., Telesford, J. M., Varner, F. A., and Richman, S. B. (2012). Observed gender differences in african american motherchild relationships and child behavior. Fam. Relat. 61, 129-141. doi: 10.1111/j.1741-3729.2011.00688.x

Martin, B. A., Cui, M., Ueno, K., and Fincham, F. D. (2013). Intimate partner violence in interracial and monoracial couples. Fam. Relat. 62, 202-211. doi: 10.1007/s10896-016-9809-z

McCarthy, B., and Casey, T. (2008). Love, sex, and crime: adolescent romantic relationships and offending. Am. Sociol. Rev. 73, 944-969. doi: $10.1177 / 000312240807300604$

Medrano, A., Miranda, M., and Figueras, V. M. (2017). Violencia de pareja contra las mujeres en México: una mirada a la atención del sector salud desde una perspectiva interseccional. Multidiscip. J. Gender Stud. 6, 1231-1262. doi: 10.4471/generos.2017.2131

Mitchell, B. A. (2010). Happiness in midlife parental roles: a contextual mixed methods analysis. Fam. Relat. 59, 326-339. doi: 10.1111/j.1741-3729.2010.00605.x

Padrós, M. (2012). Attractiveness male models in adolescence. Mascul. Soc. Change 1, 165-183. doi: $10.4471 / \mathrm{mcs} .2012 .10$

Parsons, T., and Bales, R. (1955). Family, Socialization and Interaction Process. New York, NY: The Free Press.

Puigvert, L. (2016). Female university students respond to gender violence through dialogic feminist gatherings. Int. Multidiscip. J.Soc. Sci. 5, 183-203. doi: $10.17583 /$ rimcis.2016.2118

Reale, E., Avramov, D., Canhial, K., Donovan, C., Flecha, R., Holm, P., et al. (2017). A review of literature on evaluating the scientific, social and political impact of social sciences and humanities research. Res. Eval. rvx025. doi: 10.1093/reseval/rvx025. Available online at: https://academic.oup.com/rev/ advance-article/doi/10.1093/reseval/rvx025/3978693

Ríos, O., and Christou, M. (2010). Más allá del lenguaje sexista: actos comunicativos en las relaciones afectivo-sexuales de los y las adolescentes. Rev. Signos 43, 311-326. doi: 10.4067/S0718-09342010000400004

Rollins, A., and Hunter, A. G. (2013). Racial socialization of biracial youth: maternal messages and approaches to address discrimination. Fam. Relat. 62, 140-153. doi: 10.1111/j.1741-3729.2012.00748.x

Schrock, D., and Schwalbe, M. (2009). Men, masculinity and manhood acts. Annu. Rev. Sociol. 35, 277-295. doi: 10.1146/annurev-soc-070308-115933
Schubert, T., and Valls-Carol, R. (2015). Análisis de contenido de las interacciones online de las adolescentes ¿̇lenguaje del deseo o de la ética? Commun. Soc. Change 3, 77-99. doi: 10.4471/csc.2015.1788

Schutz, A. (1967). The Phenomenology of the Social World. Evanston, IL: Northwestern University Press.

Shaffer, A., Suveg, C., Thomassin, K., and Bradbury, L. L. (2012). Emotion socialization in the context of family risks: links to child emotion regulation. J. Child Fam. Stud. 21, 917-924. doi: 10.1007/s10826011-9551-3

Shumka, L., Strega, S., and Hallgrimsdottir, H. K. (2017). "I Wanted to Feel like a Man again": hegemonic masculinity in relation to the purchase of street-level sex. Front. Sociol. 2:15. doi: 10.3389/fsoc.2017.00015

Soler, M. (2017). Achieving Social Impact: Sociology in the Public Sphere. Dordrech: Springer.

Teaster, P. B., Roberto, K. A., and Dugar, T. A. (2006). Intimate partner violence of rural aging women. Fam. Relat. 55, 636-648. doi: 10.1111/j.1741-3729.2006.00432.x

Urpí, C., and Naval, C. (2006). Sobre la educación estética en el ámbito familiar. Stud.Philos. Educ. 25, 159-173. doi: 10.1007/s11217-006-0007-y

Valls, R., Duque, E., and Puigvert, L. (2008). Gender Violence amongst teenagers: socialization and prevention. Violence Against Women 14, 759-785. doi: $10.1177 / 1077801208320365$

Valls, R., Puigvert, L., Melgar, P., and García-Yeste, C. (2016). Breaking the silence at the Spanish universities: the first research about violence against women. Violence Against Women 22, 1519-1539. doi: 10.1177/1077801215 627511

Vidu, A., Valls, R., Puigvert, L., Melgar, P., and Joanpere, M. (2017). Second Order of Sexual Harassment - SOSH. Multidiscip. J. Educ. Res. 7, 1-26. doi: 10.17583/remie.2017.2505

Yount, K. M., and Li, L. (2009). Women's "justification" of domestic violence in Egypt. J. Marriage Fam. 71, 1125-1140. doi: 10.1111/j.1741-3737.2009. 00659.x

Conflict of Interest Statement: The authors declare that the research was conducted in the absence of any commercial or financial relationships that could be construed as a potential conflict of interest.

Copyright (C) 2018 Rios-González, Peña Axt, Duque Sánchez and De Botton Fernández. This is an open-access article distributed under the terms of the Creative Commons Attribution License (CC BY). The use, distribution or reproduction in other forums is permitted, provided the original author(s) and the copyright owner(s) are credited and that the original publication in this journal is cited, in accordance with accepted academic practice. No use, distribution or reproduction is permitted which does not comply with these terms. 